\title{
Identification and Evaluation of the Ways of Meeting Patients' Expectations from a Hospital: An AHP- Weighted QFD Case Study In A Pediatric Hospital
}

\author{
N. Özgür Doğan1 $\odot$, Hazal Akbal2 $\odot$
}

\begin{abstract}
The purpose of this study is to determine the expectations of pediatric patients from a hospital and find out feasible solutions to address these expectations. In accordance with this purpose, an AHP-weighted QFD case study was carried out in a pediatric hospital in Turkey. In order to determine the expectations of pediatric patients; face-to-face and semistructured interviews were used and the natural environment of the hospital was observed in many different times. Expectations of the children constituted the left part of the House of Quality (HoQ) of QFD and were weighted using the AHP. Then, technical requirements offering solutions to expectations of children were defined, other parts of the house were added and the whole HoQ was completed. The results show that, from the children's point of view, accommodation services was found as the most important factor and arrangement of the patient rooms as the most important sub-factor. All remaining factors and sub-factors were also evaluated and prioritized. It is hoped that this study can contribute to the related literature and the QFD model developed in the study can be taken as an example by similar and/or different hospitals. Finally, the limitations of this study and future research directions are outlined.
\end{abstract}

\section{Keywords}

Analytic hierarchy process; quality function deployment; pediatric hospital; patient provider communication; patient expectations

\section{Introduction}

There are many different health institutions actively involved in the delivery of health services. In order for these health institutions to increase their market share and survive against their competitors, they need to be able to respond to the needs and expectations of service buyers. People who purchase health services want to leave the health institution happily and having a successfully completed treatment in hand. Apart from the medical services to be provided to the patient during the treatment period; communication with the patient, cleanliness of the place security, nutrition, and physical conditions will also affect the health status of her/ him. Each patient doesn't leave health institution with the same level of satisfaction.

1 N. Özgür Doğan (Doç. Dr.), Nevşehir Hacı Bektaş Veli Üniversitesi, îktisadi ve İdari Bilimler Fakültesi, Nevşehir, Türkiye. E-posta: nodogan@ nevsehir.edu.tr ORCID: 0000-0002-7892-1550

2 Corresponding author: Hazal Akbal (Öğr. Gör.), Niğde Ömer Halisdemir Üniversitesi, Zübeyde Hanım Sağlık Hizmetleri MYO, Niğde, Türkiye. E-posta: hazalakbal@ohu.edu.tr ORCID: 0000-0002-5129-9773

To cite this article: Dogan, N. O., \& Akbal, H. (2020). Identification and evaluation of the ways of meeting patients' expectations from a hospital: An ahp-weighted qfd case study in a pediatric hospital. Istanbul Business Research, 49(2), 224-247. http://doi.org/10.26650/ ibr.2020.49.0070 
While a patient may experience dissatisfaction with nutritional services, another patient may be satisfied with these services and perhaps dissatisfied with the communication styles of health personnel. This issue is especially important in pediatric hospitals. Children who receive services from health institutions have different behavioral structures when compared with adults and therefore they require a more sensitive approach. Every child applying to the health institution can be happy and comfortable by getting rid of the fears about the illness process and this will contribute to meet the demands and expectations of the pediatric patients and provide a better-quality service.

As mentioned in the above paragraphs, children are different from adults and this issue must also be considered while delivering healthcare services to them. According to World Health Organization, a child is a human being under the age of 18 (World Health Organization, 2019). In 2017, population of Turkey is 80,8 million and children constitute 22,8 million of this population, which corresponds to $28,3 \%$ of the total (Turkish Statistical Institute, 2018). If we look at the world's population; in 2017, total population is 7,6 billion and children constitute $26 \%$ of this total (United Nations, 2017). Their behavioral sensitivities and high population size explain the importance of focusing on children.

Children who receive services from health institutions have different behavioral structures when compared with adults and therefore they require a more sensitive approach. Children's needs and expectations are different than adults. These needs and expectations are also different for health services. However, many healthcare providers ignore this distinction and they treat pediatric patients as adults.

The aim of this study was to determine the expectations of pediatric patients from a hospital and to identify the way of meeting these expectations. In accordance with this purpose, AHP and QFD techniques were used. The reason for using the AHP method is that it presents problems hierarchically. Thus, multi-dimensional problems are reduced to one dimension. The AHP method was used for determining the importance degrees of the wishes of pediatric patients and their prioritization. AHP is a method that needs the opinions of the decision makers. Therefore, AHP is the most appropriate method as the study is designed from a children's point of view. OFD is a particularly effective method in the transformation of the customer wants into the technical requirements. Some healthcare providers ignore children's expectations and requests from the hospital or it cannot correctly understand and convey the wishes of children. The QFD method has been used to design a hospital that will make children happy by listening to children's voices.

The study was conducted in a pediatric hospital in the Niğde province of Turkey. In order to determine the expectations of pediatric patients, traditional techniques such as face to face interview, observation, and semi-structured interview were used and, in addition to these techniques, expert opinions were obtained. In order to achieve the goal of fulfilling the 
patient expectations, all factors and sub-factors were also evaluated and prioritized. The results show that from the children's point of view, accommodation services were found as the most important factor and arrangement of the patient rooms as the most important sub-factor. According to findings, these two factors were found as fulfilling the expectations of children from the hospital: "redesigning patient rooms (e.g.: coloring and painting the walls)" and "building a bookshelf in each patient room".

The rest of this study is organized as follows. Section 2 reviews the literature. Section 3 discusses the methodology. Section 4 presents the findings. Finally, Section 5 concludes.

\section{Literature Review}

When it comes to talking about the match between the customers' demands and the product or service providers' supplies, perhaps the first method that comes to mind is the Quality Function Deployment (QFD). The OFD is particularly effective on the transformation of the customer wants into the technical requirements. According to Chan and Wu (2002), QFD is a concept defined as a tool that transforms customer needs into product development and production with appropriate technical requirements at every stage of production.

The QFD method has also been used in healthcare sector. It seems that this method has been started to be applied in various fields of healthcare institutions, specifically hospitals. Product development (Hu \& Yeh, 2011; Khare \& Sharma, 2013; Shih \& Chen, 2013), designing a medical diagnostic scale (Shuo, Lee \& Huang, 2009), health infrastructure design (Dehe \& Bamford, 2017), health system design (Gonzales, et al., 2006; Ahmed, Islam \& Al-wahaibi, 2006; Yang \& Kim, 2013), the quality of health sites (Chang \& Kim, 2010), and the quality of health education (Chou, 2004) are among the applications in the related literature. Since this study focuses on expectations of patients, the literature about the studies with the QFD method addressing patient needs and expectations are summarized in a detailed way in Table 1.

Also, the literature on the AHP for pediatric services is included in listed below Table 2.

In this study, expectations of children from a pediatric hospital were tried to be determined and potential solution alternatives to meet these expectations were identified. This study differs from previous studies in that the research was carried out in a pediatric hospital and with pediatric patients. Therefore, it is expected that this study may contribute to the related literature and shed light on the future studies focusing on pediatric patients and/or pediatric hospitals. 
Table 1

The Literature Review About the Studies with QFD Method Addressing Patient Needs and Expectations

\begin{tabular}{|c|c|c|}
\hline Authors & Scope and Aim & Prominent Expectations \\
\hline $\begin{array}{l}\text { Radharamanan \& } \\
\text { Godoy, } 1996\end{array}$ & $\begin{array}{l}\text { Determining how to meet patient needs in the Uni- } \\
\text { versity Hospital at Santa Maria (UHSM). }\end{array}$ & $\begin{array}{l}\text {-rapid response } \\
\text {-appropriate treatment } \\
\text {-appropriate counseling service }\end{array}$ \\
\hline $\begin{array}{l}\text { Einspruch, } \\
\text { Omachonu \& } \\
\text { Einspruch, } 1996\end{array}$ & $\begin{array}{l}\text { The purpose of this study was to discuss the applica- } \\
\text { tion of the QFD process to rehabilitation in a US } \\
\text { rehabilitation center. }\end{array}$ & $\begin{array}{l}\text {-to the need to get well } \\
\text {-ease of referrals }\end{array}$ \\
\hline $\begin{array}{l}\text { Doğan \& Arıcan, } \\
2008\end{array}$ & $\begin{array}{l}\text { Determining customer expectations in pharmaceuti- } \\
\text { cal industry at Turkey. }\end{array}$ & $\begin{array}{l}\text {-the drug should not put the patient to sleep } \\
\text {-quick effect } \\
\text {-long effect } \\
\text {-low side effect } \\
\text {-ease of use. }\end{array}$ \\
\hline $\begin{array}{l}\text { Chiou, \& Cheng, } \\
2008\end{array}$ & Identifying customer needs at Taiwan health service. & $\begin{array}{l}\text {-convenience } \\
\text {-cleanliness } \\
\text {-physician care }\end{array}$ \\
\hline $\begin{array}{l}\text { Yapraklı \& Güzel, } \\
2010\end{array}$ & $\begin{array}{l}\text { Finding the ways of meeting patient expectations at } \\
\text { special medical centers in Erzurum. }\end{array}$ & $\begin{array}{l}\text {-staff training and civility } \\
\text {-treatment pays } \\
\text {-easy access to the results of patients }\end{array}$ \\
\hline $\begin{array}{l}\text { Kuo, Wu, Hsu \& } \\
\text { Chen, } 2010\end{array}$ & $\begin{array}{l}\text { Evaluating the quality of outpatient services for } \\
\text { elderly patients at Taiwan. }\end{array}$ & $\begin{array}{l}\text {-professional medical care services } \\
\text {-sufficient knowledge to answer patients' } \\
\text { questions } \\
\text {-fast services } \\
\text {-providing proper medical equipment to } \\
\text { patients }\end{array}$ \\
\hline $\begin{array}{l}\text { Aktepe, et al., } \\
2011\end{array}$ & $\begin{array}{l}\text { Redesigning hospital services by determining } \\
\text { customer needs and requirements at a University } \\
\text { Hospital in Turkey. }\end{array}$ & $\begin{array}{l}\text {-reliability } \\
\text {-physical characteristics } \\
\text {-assurance }\end{array}$ \\
\hline Chou, et al., 2014 & $\begin{array}{l}\text { Investigating new approaches to evaluate medical } \\
\text { service gap between current service state and cus- } \\
\text { tomer expectations at medical centers in Taiwan. }\end{array}$ & $\begin{array}{l}\text {-redesign hospital transportation and park- } \\
\text { ing area } \\
\text {-medical staff's manner } \\
\text {-block out irrelevant persons } \\
\text {-patients' privacy }\end{array}$ \\
\hline $\begin{array}{l}\text { Hashemi, Marzban } \\
\text { \& Delavari, } 2015\end{array}$ & $\begin{array}{l}\text { İmproving the quality of services in a chemotherapy } \\
\text { unit services of Nemazee Hospital in Iran. }\end{array}$ & $\begin{array}{l}\text {-access, } \\
\text {-suitable hotel services } \\
\text {-satisfactory and effective relationships } \\
\text {-clinical services. }\end{array}$ \\
\hline $\begin{array}{l}\text { Kıdak, Arslan \& } \\
\text { Burmaoğlu, } 2016\end{array}$ & $\begin{array}{l}\text { Determining the needs and expectations of patients } \\
\text { about health services at a state hospital in Izmir. }\end{array}$ & $\begin{array}{l}\text {-improvement of inspection system } \\
\text {-development of appointment system } \\
\text {-giving communication and behavior train- } \\
\text { ing to doctors }\end{array}$ \\
\hline $\begin{array}{l}\text { Ariani, Napiyani } \\
\text { \& Wijaya, } 2017\end{array}$ & $\begin{array}{l}\text { Identifying priority needs of customer and staff } \\
\text { to improve the quality of service at Blahbatuh II } \\
\text { Health Centre in Endonezya. }\end{array}$ & $\begin{array}{l}\text {-friendly staff } \\
\text {-fast and timely service } \\
\text {-effective treatment } \\
\text {-performance-based reward system } \\
\text {-a staff training program for the health } \\
\text { center }\end{array}$ \\
\hline $\begin{array}{l}\text { Gündoğdu \& } \\
\text { Görener, } 2017\end{array}$ & $\begin{array}{l}\text { Focusing on patient expectations for the blood- } \\
\text { taking process in a private hospital at Turkey. }\end{array}$ & $\begin{array}{l}\text {-expert personel } \\
\text {-providing training for healthcare workers } \\
\text {-having a visual processing scheme }\end{array}$ \\
\hline
\end{tabular}


Table 2

The Literature on the AHP for Pediatric Services

\begin{tabular}{|c|c|c|}
\hline Authors & Scope and Aim & Prominent Expectations \\
\hline $\begin{array}{l}\text { Hancerliogullari, Hancer- } \\
\text { liogullari \& Koksalmis, } \\
2017\end{array}$ & $\begin{array}{l}\text { Determining the most suitable anesthesia } \\
\text { method for circumcision surgery in pediatric } \\
\text { surgery. }\end{array}$ & $\begin{array}{l}\text {-convenience } \\
\text {-reliability } \\
\text {-duration } \\
\text {-psychology }\end{array}$ \\
\hline Faggiano et al., 2017 & $\begin{array}{l}\text { To evaluate different type and manufacturers } \\
\text { of intensive care ventilators in order to sup- } \\
\text { port the healthcare decision-making process } \\
\text { about the choice to adopt the best available } \\
\text { technology for ventilation of pediatric patient } \\
\text { in intensive care units at Bambino Gesù } \\
\text { Children's Hospital. }\end{array}$ & $\begin{array}{c}\text {-feasibility } \\
\text {-safety } \\
\text {-efficacy } \\
\text {-costs } \\
\text {-organizational characteristics } \\
\text {-technical characteristics of the technology }\end{array}$ \\
\hline Antmen \& Minç, 2018 & $\begin{array}{l}\text { To selection of ventilator in a child intensive } \\
\text { care unit of a hospital in Adana county. }\end{array}$ & $\begin{array}{l}\text {-being suitable for the child } \\
\text {-mode } \\
\text {-battery } \\
\text {-to make different measurements } \\
\text {-maneuver } \\
\text {-ease of use } \\
\text {-maintenance }\end{array}$ \\
\hline Yu et al., 2018 & $\begin{array}{c}\text { To developed an evidence-based pediatric } \\
\text { drug evaluation model. }\end{array}$ & $\begin{array}{c}\text {-effectiveness } \\
\text {-safety } \\
\text {-applicability } \\
\text {-economics } \\
\text {-pharmaceutical characteristics }\end{array}$ \\
\hline Di Mauro et al., 2019 & $\begin{array}{c}\text { To evaluate the best intensive care ventilator } \\
\text { manufacturers out in different pediatric inten- } \\
\text { sive care units of Bambino Gesù Children's } \\
\text { Hospital. }\end{array}$ & $\begin{array}{l}\text {-clinical } \\
\text {-technical } \\
\text {-organizational } \\
\text {-economic } \\
\text {-safety domain }\end{array}$ \\
\hline Lin et al., 2020 & $\begin{array}{l}\text { Establish indicator system for evaluation of } \\
\text { rational drug use in children with primary } \\
\text { nephrotic syndrome. }\end{array}$ & $\begin{array}{c}\text {-importance, } \\
\text {-accessibility, } \\
\text {-degree of familiarity, and } \\
\text {-the evidence of judgment. }\end{array}$ \\
\hline
\end{tabular}

\section{Materials and Methods}

The population of the study consisted of children aged 7-12 who came to the additional service building of the Niğde Pediatric Hospital. In order to determine the expectations of pediatric patients, face-to-face interviews and semi-structured interviews were used. Since we had difficulty finding a data collection procedure from previous studies on this subject, we tried to develop a data collection tool (Appendix 1). The data of the study were collected by using the expectation measurement criteria in Appendix 1 for determining the expectation of pediatric patients from the pediatric hospital. These expectations criteria were transformed into technical characteristics with the help of the AHP and QFD methods, and then, the applications enabling increases in the service quality were determined. 


\section{Analytic Hierarchy Process (AHP)}

The AHP method enables decision-makers to structure a complex problem in the form of a simple hierarchy and assess a big number of quantitative and qualitative factors in a systematic manner (Radivojeviç \& Gajoviç, 2014: 342). The AHP has been widely applied and extensively studied in a number of fields since it was developed by Thomas L. Saaty in the 1970s (Zhang et al., 2019: 476). It is a process of modeling and quantifying decision makers' decision thinking processes for complex systems. By using AHP, decision makers decompose the complex problems into several levels and factors, and make simple comparisons and calculations among the factors (Chang, Yang \& Dong, 2018: 8).

The first stage of the method begins with the definition of a multi-criteria decision-making problem. The goal, criteria and alternatives to be achieved are transformed into a hierarchic structure as shown in Figure 1.

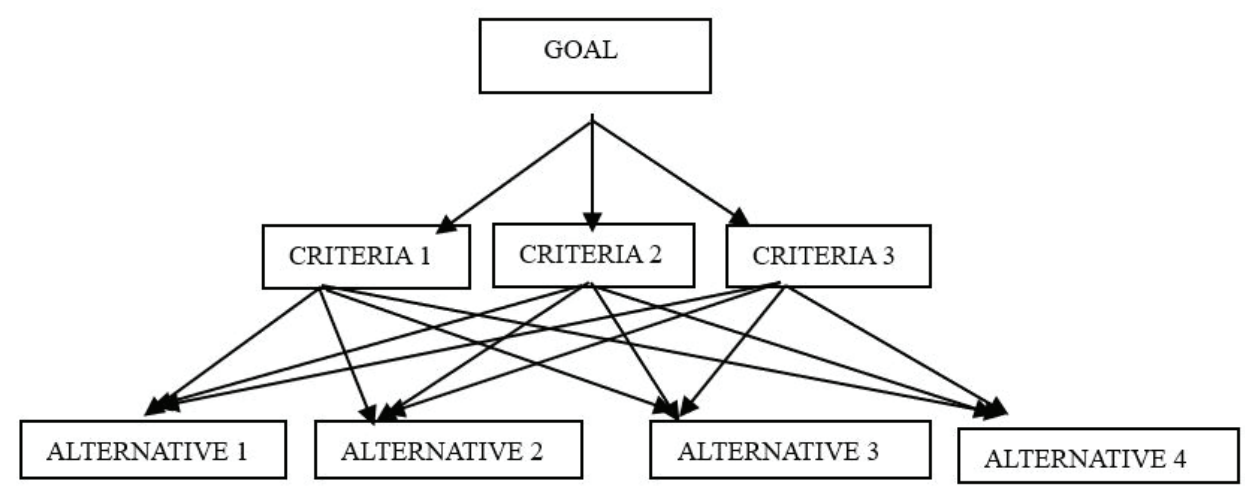

Figure 1. Hierarchic structure of AHP (Ge \& Liu, 2019)

In the second stage, the criteria determined are compared with each other, and a binary comparison matrix form is obtained with expert opinion. When constructing these matrices, a scale is used that covers the values between 1 and 9, which are expressed in Table 3 . If the elements in the matrix are compared to itself, a numerical value of 1 is given (Oktafianto et al., 2018: 180).

Table 3

Saaty's AHP Binary Comparisons Scale (Javid, Nejat \& Hayhoe, 2014)

\begin{tabular}{cc}
\hline Intensity of Importance & Definition \\
\hline 1 & Equal Importance \\
3 & Moderate Importance \\
5 & Strong Importance \\
7 & Very Strong Importance \\
9 & Extreme Importance \\
$2,4,6,8$ & Values Between Two Values \\
\hline
\end{tabular}


In the third step, the normalized matrix is obtained by dividing the value of each column by the respective column total. Then importance degrees are obtained by averaging the row values of the normalized matrix (Bang \& Chang, 2013: 5747).

In the fourth step, the consistency ratio (CR) is examined to ensure the reliability of the analysis. If the $\mathrm{CR} \leq 0.10$, the decisions of the experts are considered as appropriate (Chung $\& \mathrm{Na}, 2018:$ 134). When calculating this ratio, the Weighted Total Vector (WTV) is generated by multiplying the initial comparison matrix and importance degrees. The resulting matrix elements are divided into importance degrees. The mean of these values is obtained; and the result is called $\lambda \max$. Then Consistency Index $(\mathrm{CI})$ is calculated: $\mathrm{CI}=(\lambda \max -n) /(\mathrm{n}-1)(\mathrm{Bang}$ \& Chang, 2013:5747). After CI is obtained, the Random Index (RI) value is found. Table 4 shows the RI values according to the factors.

Table 4

Random Index (Saaty, 2008)

\begin{tabular}{|c|c|c|c|c|c|c|c|c|c|c|c|c|c|c|c|}
\hline $\mathbf{n}$ & 1 & 2 & 3 & 4 & 5 & 6 & 7 & 8 & 9 & 10 & 11 & 12 & 13 & 14 & 15 \\
\hline RI & 0 & 0 & 0.52 & 0.89 & 1.11 & 1.25 & 1.35 & 1.40 & 1.45 & 1.49 & 1.52 & 1.54 & 1.56 & 1.58 & 1.59 \\
\hline
\end{tabular}

The consistency ratio is defined as the ratio of the consistency index to the random index and the formula of CR $=\mathrm{CI} / \mathrm{RI}$ is used (Falsini, Fondi \& Schiraldi, 2012: 4823). If this ratio is greater than 0.10, the decision matrix is inconsistent. Decisions should be reviewed and improved. In the last stage, a final decision is made based on the results obtained (Varajao \& Cruz-Cunha, 2013: 3345).

\section{Quality Function Deployment (QFD)}

Quality function deployment (QFD) is an overall method that provides a means of translating customer requirements into the appropriate technical requirements for each stage of product development and production (Chan \& Wu, 2002: 463). The method was first used and defined by Akao in Japan in 1966 as a method for quality assessment in the shipyard design process. In the early 1990s, and after investigating the Japanese product design practices in detail, QFD techniques were adopted by U.S. firms to reduce time to market, decrease costs of design and manufacture, and increase overall product quality (Morris \& Morris, 1999: 131). QFD is an analysis technique that portrays how requirements and expectations are satisfied, and makes a trade-off between conflicting needs and expectations. The analysis uses a diagram known as House of Quality (HoQ), shown in Figure 2. 


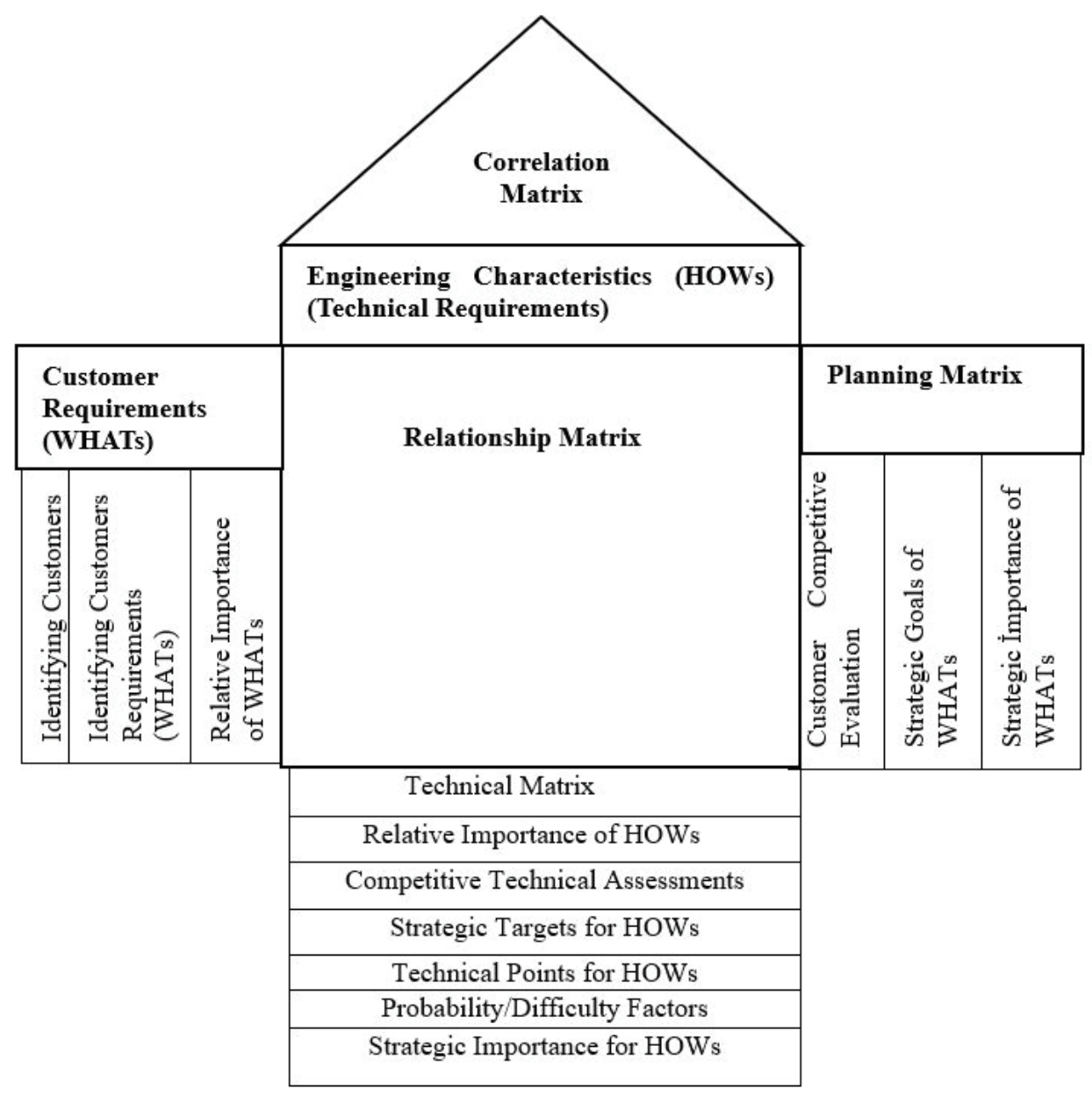

Figure 2. House of Quality (Park, Ham \& Lee, 2012)

The implementation steps of the QFD method are described below.

1) Identifying and prioritizing customer requirements: The first step is to identify customer requirements, which usually are determined by personal interviews and/or focus groups (Matzler \& Hinterhuber, 1998: 35). The most important and time consuming step in determining customer requirements is listening to the voice of customers (VOC). Customer requirements, defined by interviews, brainstorming, surveys, or feedback; are characterized by the voice of customer (Özgener, 2003: 972). Then, the importance degree of each customer voice (WHATs) is determined.

2) Identifying engineering characteristics (technical requirements): This step is determined by a design team, and design measures or product features that are developed by this team can be used to address the defined customer requirements (Özgener, 2003: 972). In this 
stage, we try to find the answer to the following question: How can we change the product? (Matzler \& Hinterhuber, 1998: 35).

3) Constructing the relationship matrix: The principal function of the relationship matrix is to transform requirements expressed by customers into product characteristics by establishing a connection between customer requirements (WHATs) and the technical requirements (HOWs) designed to improve a product (Chen \& Huang, 2011: 388). This relationship is expressed by various symbols or numbers as shown in Table 5.

Table 5

Relationship Matrix Scale Scores (Ahmed, Islam \& Al-wahaibi, 2006; Ardıç, Çevik \& Göktaş, 2008)

\begin{tabular}{lccc}
\hline Meaning & Symbol & US System Score & Japan System Score \\
\hline Strong relationship & $\mathbf{0}$ & 9 & 5 \\
Medium relationship & $\circ$ & 3 & 3 \\
Weak relationship & $\Delta$ & 1 & 1 \\
\hline
\end{tabular}

4) Constructing the correlation matrix: In this step, engineering characteristics are developed and the correlation between each of these characteristics is determined (Park, Ham \& Lee, 2012: 328). The degree of relationship between engineering characteristics can be indicated by strong ' $\bullet$ ' and weak ' $O$ ' symbols.

5) Estimation of costs, feasibility and technical difficulty: This step is necessary for making reasonable choices and includes quantifying costs, feasibility and technical difficulty of each design attribute (Matzler \& Hinterhuber, 1998: 36).

\section{Results and Discussion}

The study was carried out during February and March of 2019 with patients attending the additional service building of the Pediatric Hospital of the Niğde Education and Research Hospital. The population of the study was limited to pediatric patients of 7 to 12 years of age (totally 24 children). While collecting the data of the study, the families of the pediatric patients received an explanation about participation in the study. After the oral and written consent of the families was obtained, the data were collected in an environment where the factors affecting the data collection process were minimized. Children who were treated for severe or infectious diseases and hospitalized for emergency reasons were not included in the study.

The factors that affect patients' expectations from the hospital are considered as three main criteria and eleven sub-criteria as shown in Figure 3. In other words, Figure 3 reflects the hierarchical structure of AHP. These three main criteria are service environment, personnel-patient interaction and accommodation services. The sub-criteria determined for the service environment are appearance of treatment equipment, clothes of hospital personnel, care information for disease and treatment services. The sub-criteria related to personnel-patient 
interaction are the behaviors of doctors, nurses and other health personnel. The sub-criteria related to accommodation services are nutrition services, arrangement of patient rooms, appearance of rest chairs and appearance of patient beds.

In order to measure the expectations, the children who participated in the study were asked the questions in Appendix 1 according to these predetermined criteria and sub-criteria. Then, these expectation criteria were transformed into engineering characteristics, and a roadmap showing the prioritization of possible applications to increase service quality was determined.

A six-stage process was followed within the scope of this study:

Stage 1. Gathering the expectations of pediatric patients: At this stage, the patient's wishes and requirements were determined by focusing on the child's own statements.

Stage 2. Determining the importance degrees of the wishes of pediatric patients: The identified wishes and requirements are prioritized according to their importance degrees. The AHP method was used for prioritization.

Stage 3. Transforming the wishes of pediatric patients into engineering characteristics: It was determined how to fulfill the wishes and/or requirements.

Stage 4. Constructing the relationship matrix: At this stage, the relationship matrix was developed between patient requirements and engineering characteristics.

Stage 5. Constructing the planning and the correlation matrix: The planning matrix was constructed by evaluating the hospital's current situation, future situation and improvement ratio. Importance and percent importance degrees of technical requirements were determined. Then, the correlation matrix, expressed as the roof of House of Quality (HoQ) was constructed and the way of affecting the engineering characteristics was determined.

Stage 6. Completing the HoQ: Finally, the HoQ was built. 


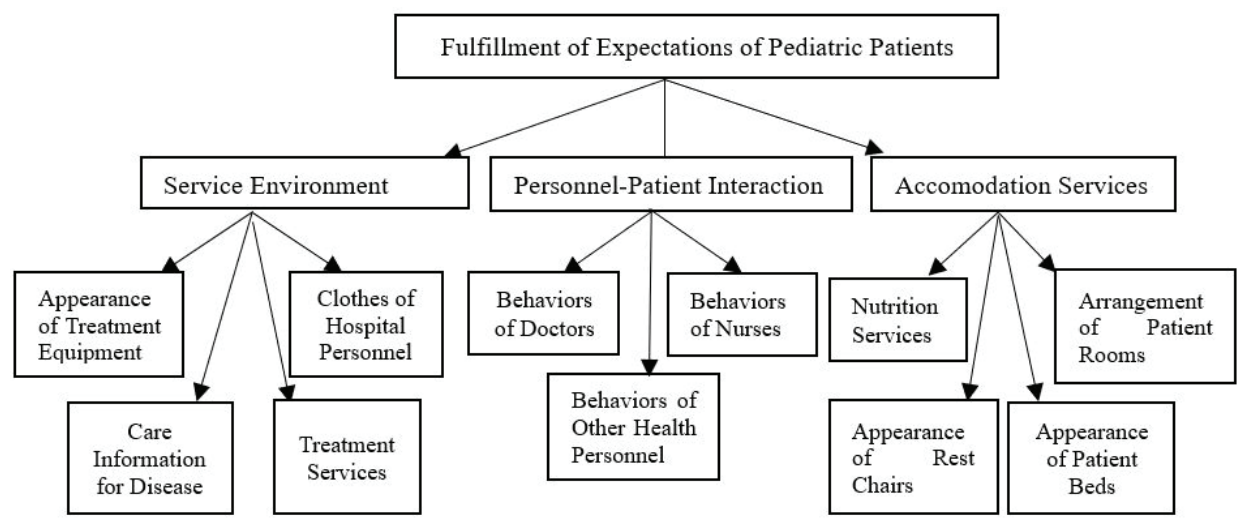

Figure 3. Hierarchical structure of AHP

In order to achieve the overall goal of fulfilling the patient expectations, firstly the main criteria were compared according to the importance scale developed by Saaty. Afterwards, normalization was made and importance degrees (ID) were calculated for each criterion. The study was conducted with 24 pediatric patients. However, it would be unnecessary information to show the comparison matrices separately for 24 patients. For this reason, comparison matrices conducted for only one child who was randomly selected and called "Child-1". Comparison matrices for criteria and sub-criteria for child 1 were also created for other children. These matrices are presented in Appendix 2 and Appendix 3 using abbreviations of criteria and sub-criteria.The comparisons and other related calculations made for Child-1 were also made for each child who participated in the interviews, and the obtained values are shown in Appendix 2. The table in Appendix 3 shows the overall common weights of sub-criteria. The common and/or overall weights of all criteria/sub-criteria can be seen in Appendix 2 and Appendix 3 with both average mean (AM) and geometric mean (GM) values. Table 6 shows the result of the comparisons and calculations of main criteria for Child-1. Furthermore, the consistency related values are summarised in Table 6 .

Table 6

Importance Degrees of Main Criteria for Child-1

\begin{tabular}{|c|c|c|c|c|c|c|}
\hline & $\begin{array}{c}\text { Service } \\
\text { Environment } \\
\end{array}$ & $\begin{array}{c}\text { Personnel-Patient } \\
\text { Interaction }\end{array}$ & $\begin{array}{c}\text { Accomodation } \\
\text { Services }\end{array}$ & ID & WTV & WTV/ID \\
\hline Service Environment & 1,00 & 7,00 & 5,00 & 0,73 & 2,27 & 3,13 \\
\hline $\begin{array}{l}\text { Personnel-Patient } \\
\text { Interaction }\end{array}$ & 0,14 & 1,00 & 0,33 & 0,08 & 0,25 & 3,01 \\
\hline Accomodation Services & 0,20 & 3,00 & 1,00 & 0,19 & 0,59 & 3,04 \\
\hline
\end{tabular}

As a result of the interview with the first child, importance degrees (ID) were calculated for each criterion. Importance degrees were obtained by averaging the row values of the 
normalized matrix. As a result of the interview with the first child, it can be seen from Table 6 that the ID of the service environment criterion is 0.73 . The ID for the personnel-patient interaction criterion is 0.08 , and the ID for the accommodation criterion is 0.19 . In this case, the most important main criterion for the first child patient is the service environment in the hospital. The CR is used to determine the consistency of the child's decision. CR value is found as 0.05 for Child- 1 , and since $C R \leq 0.10$, it can be stated that Child- 1 is consistent in his/her decisions.

After comparing the main criteria, the sub-criteria were compared among themselves. Table 7 shows the result of the comparisons and all other related calculations of sub-criteria of service environment for Child-1.

Table 7

Importance Degrees of Sub-Criteria of Service Environment for Child-1

\begin{tabular}{|c|c|c|c|c|c|c|c|}
\hline & $\begin{array}{c}\text { Appearance } \\
\text { of Treatment } \\
\text { Equipment }\end{array}$ & $\begin{array}{c}\text { Clothes of } \\
\text { Hospital } \\
\text { Personnel } \\
\end{array}$ & $\begin{array}{l}\text { Care Informa- } \\
\text { tion for Disease }\end{array}$ & $\begin{array}{c}\text { Treatment } \\
\text { Services }\end{array}$ & ID & WTV & WTV/ID \\
\hline $\begin{array}{l}\text { Appearance of Treat- } \\
\text { ment Equipment }\end{array}$ & 1,00 & 0,33 & 3,00 & 0,25 & 0,14 & 0,58 & 4,06 \\
\hline $\begin{array}{l}\text { Clothes of Hospital } \\
\text { Personnel }\end{array}$ & 3,00 & 1,00 & 4,00 & 0,50 & 0,30 & 1,26 & 4,19 \\
\hline $\begin{array}{l}\text { Care Information for } \\
\text { Disease }\end{array}$ & 0,33 & 0,25 & 1,00 & 0,20 & 0,07 & 0,29 & 4,04 \\
\hline Treatment Services & 4,00 & 2,00 & 5,00 & 1,00 & 0,48 & 2,02 & 4,17 \\
\hline
\end{tabular}

According to Table 7, the sub-criteria of service environment are arranged in decreasing order of importance as follows: treatment services, clothes of hospital personnel, appearance of treatment equipment, and care information for disease. CR value is 0.04 so Child- 1 is consistent in his/her decisions.

Table 8 shows the result of the comparisons and all other calculations of sub-criteria of personnel-patient interaction for Child-1.

Table 8

Importance Degrees of Sub-Criteria of Personnel-Patient Interaction for Child-1

\begin{tabular}{|c|c|c|c|c|c|c|}
\hline & $\begin{array}{l}\text { Behaviors of } \\
\text { Doctors }\end{array}$ & $\begin{array}{c}\text { Behaviors of } \\
\text { Nurses }\end{array}$ & $\begin{array}{c}\text { Behaviors of Other } \\
\text { Health Personnel }\end{array}$ & ID & WTV & WTV/ID \\
\hline $\begin{array}{l}\text { Behaviors of Doc- } \\
\text { tors }\end{array}$ & 1,00 & 0,50 & 0,17 & 0,10 & 0,31 & 3,01 \\
\hline Behaviors of Nurses & 2,00 & 1,00 & 0,20 & 0,17 & 0,53 & 3,01 \\
\hline $\begin{array}{l}\text { Behaviors of Other } \\
\text { Health Personnel }\end{array}$ & 6,00 & 5,00 & 1,00 & 0,72 & 2,21 & 3,06 \\
\hline
\end{tabular}

$\lambda_{\max }=3,03 ; \mathrm{CI}=0,01 ; \mathrm{RI}=0.58 \mathrm{CR}=0,02$ (comparisons are consistent since $\mathrm{CR} \leq 0,10$ )

One can see from Table 8 that the sub-criteria related to personnel-patient interaction are arranged in decreasing order of importance as follows: behaviors of other health personnel, 
behaviors of nurses, and behaviors of doctors. It is seen that communication with other health personnel, including medical secretaries, paramedics and interns, is more important than the other two criteria. The CR value is 0.02 and consistency is assured.

Table 9 shows the result of the comparisons and all other calculations of sub-criteria of accomodation services for Child-1.

Table 9

Importance Degrees pf Sub-Criteria of Accomodation Services for Child-1

\begin{tabular}{lccccccc}
\hline & $\begin{array}{c}\text { Nutri- } \\
\text { tion } \\
\text { Services }\end{array}$ & $\begin{array}{c}\text { Arrangement } \\
\text { of Patient } \\
\text { Rooms }\end{array}$ & $\begin{array}{c}\text { Appear- } \\
\text { ance of Rest } \\
\text { Chairs }\end{array}$ & $\begin{array}{c}\text { Appearance } \\
\text { of Patient } \\
\text { Beds }\end{array}$ & ID & WTV & WTV/ID \\
\hline $\begin{array}{l}\text { Nutrition Services } \\
\text { Arrangement of Patient }\end{array}$ & 1,00 & 0,25 & 4,00 & 0,33 & 0,14 & 0,59 & 4,22 \\
Rooms & 4,00 & 1,00 & 6,00 & 2,00 & 0,48 & 2,01 & 4,17 \\
Appearance of Rest Chairs & 0,25 & 0,17 & 1,00 & 0,17 & 0,06 & 0,23 & 4,02 \\
Appearance of Patient Beds & 3,00 & 0,50 & 6,00 & 1,00 & 0,32 & 1,32 & 4,17 \\
\hline
\end{tabular}

$\lambda_{\max }=4,15 ; \mathrm{CI}=0,05 ; \mathrm{RI}=0.90 \mathrm{CR}=0,05$ (comparisons are consistent; $\mathrm{CR} \leq 0,10$ )

According to Table 9, the sub-criteria of accommodation services are arranged in decreasing order of importance as follows: arrangement of patient rooms, appearance of patient beds, nutrition services, and appearance of rest chairs. The CR value is 0.05 , so consistency is assured.

The comparisons and other related calculations made for Child-1 were also made for each child who participated in the interviews, and the obtained values are shown in Appendix 2. As a result of the group average of 24 children as shown in Appendix 2, the most important main criterion was found as accomodation services with a weight of 0.55 . It was followed by service environment (0.28) and personnel-patient interaction (0.17). The table in Appendix 3 shows the overall common weights of the sub-criteria. For example, one can see from Appendix 3 that the most important sub-criterion was found as arrangement of patient rooms with a weight of 0.27 , and the second most important sub-criterion was nutrition services with a weight of 0.18 . The common and/or overall weights of all criteria/sub-criteria can be seen in Appendix 2 and Appendix 3, with both average mean (AM) and geometric mean (GM) values. While analyzing these weights and values, the following abbreviations must be taken into consideration: service environment (K1), personnel-patient interaction (K2), accommodation services (K3), appearance of treatment equipment (K11), clothes of hospital personnel (K12), care information for disease (K13), treatment services (K14), behaviors of doctors (K21), behaviors of nurses (K22), behaviors of other health personnel (K23), nutrition services (K31), arrangement of patient rooms (K32), appearance of rest chairs (K33), and appearance of patient beds (K34).

The voices of the children were listened to and then weighted using the AHP method. This effort made it possible to identify the most important expectations and priority rankings for 
them. Expectations of children constitute the left part of the HoQ (the WHATs) and the way of meeting these expectations, namely the engineering characteristics (the HOWs) take place in the right side. This match or transformation is given in Table 10.

As a result of the interviews with 24 children, expectations were converted into engineering characteristics in order to fullfill their expectations from the hospital. The determined engineering characteristics were formed in accordance with the opinions of the senior management of the hospital under investigation. In addition, researchers, nurses and doctors working in child services and senior management of the hospital under investigation determined the relationship between these engineering and the expectations of children. In order to determine the relationship between these characteristics and the expectations of children, a scoring system from 1 to 5 was used.

After determining the relationships between engineering characteristics and expectations, a planning matrix was created. In this matrix, first of all, the current situation column describes the current situation of the hospital regarding the expectations of children. Then, based on the current situation, the future situation column was prepared containing the realization of these future expectations. The values obtained were evaluated using a scaling system from 1 to 5 . In this system, "1" indicates the worst, and " 5 " indicates the best.

The improvement ratios were obtained by dividing the values in future situation by the values in current situation column. In light of this information, the eventual (overall) importance degrees were found by multiplying the improvement ratios by importance degrees. After the eventual importance degrees were determined, the technical importance values were calculated. This calculation was made by multiplying the values of each column by the eventual importance degrees and summing the results of columns which have more than one value. Then, the percent importance values were calculated. Percentage of importance values were calculated by dividing the technical importance of each column by sum of the technical importance values, and then the obtained values were multiplied by 100 . According to these findings, two factors with importance values of 6.75 ( 25 percent) were found as the ones with the highest priorities. These two factors were "redesigning patient rooms (e.g.: coloring and painting the walls)" and "building a bookshelf in each patient room". "Building playground rooms" was found as the second important factor with a value of 4.05 (15 percent), which can enable children to forget their illnesses for a while, socialize and do various activities such as painting and playing games. The house of quality (HoQ) shown in Figure 4 was created by considering all these steps. 
Table 10

Transformation of Expectations of Pediatric Patients Into Engineering Characteristics

\begin{tabular}{ll}
\hline Criteria & Expectations of Patients (WHAT's) \\
$\begin{array}{l}\text { Service } \\
\text { Environment }\end{array}$ & $\begin{array}{l}\text { I expect the materials used in the treatm } \\
\text { to be cute. }\end{array}$ \\
& $\begin{array}{l}\text { I expect clothes of hospital personnel to } \\
\text { change. }\end{array}$
\end{tabular}

I expect to understand the care information about the disease.

I expect to non-disturbance of treatment process

Personnel-

Patient

Interaction

I expect nurses to act like friends

I expect other health personnel to act like friends

Accomodation I expect more delicious food

Services

I expect my room to be as I imagined

I expect the resting chairs to be more colorful and comfortable

I expect the patient beds to be more colorful Engineering Characteristics (HOW's)

*Abeslang can be designed in color.

*Serum hangers can be colored.

* Other materials to be used can be considered to be designed without fear and anxiety.

*Nurses may prefer uniforms that are suitable for children (e.g.: including rainbow, geometric figure, cartoon heroes)

* Doctors can choose clothes having various patterns.

*The child can be shown photos informing about the disease, stories can be told, suitable cartoons can be watched.

*The materials to be used in the treatment can be introduced according to the age and development level of the child.

* The child and their family can be informed about the disease in an explanatory language.

*Therapeutic games can be played with the child (e.g.: blowing up a balloon or blowing foam)

* Psychological preparation program can be applied to pediatric patients

* Doctors can show interest, be smiling and behave in a friendly manner towards the child

* Doctors can introduce inpatient children to other sick children and give start to communication

*Nurses can show interest, be smiling and behave in a friendly manner towards the child

* Nurses can introduce inpatient children to other sick children and give start to communication.

*The child can be welcomed by an understanding and friendly personnel from the first moment she/he arrives at the hospital

*Admission secretaries can show interest, be smiling and behave in a friendly manner towards the child

*Visual presentation can be given importance (e.g.: a smiley face can be on the plate during food presentation)

*Child-oriented food can be served (e.g.: cake, juice)

*Game rooms can be built where children can warm to other children, draw pictures, play games and perform various activities

*Patient rooms can be designed with visual attractiveness for children (e.g.: colorful or patterned walls or cupboards)

* Bookcases with story books can be built in the patient rooms for children to spend time

* Rest chairs having suitable colors, patterns and sizes for children can be used

*Fabric of rest chairs may have adequate quality to be comfortable

*Bed sheet, pillows and beds having suitable colors, and patterns for children can be used 


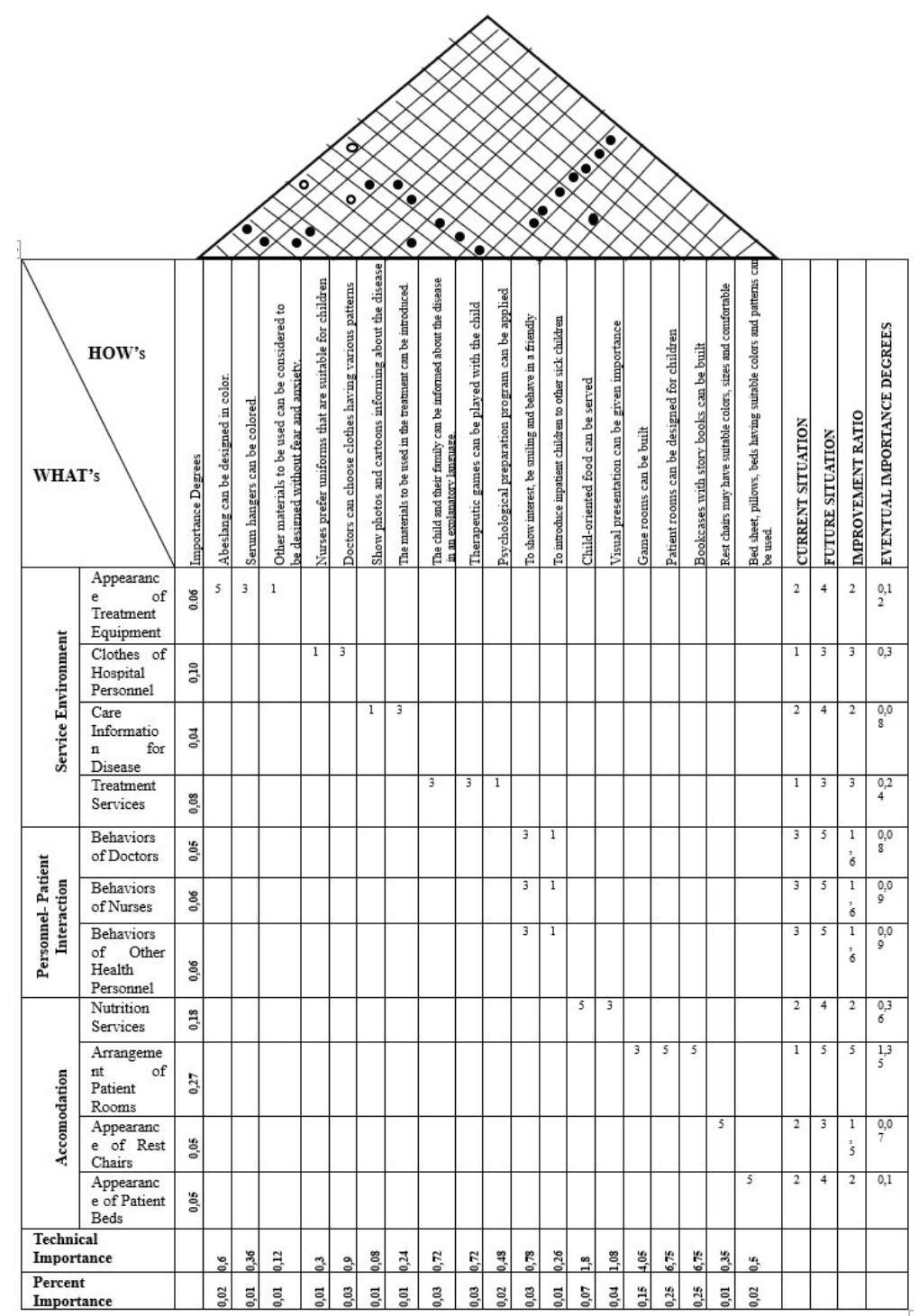

Figure 4. House of Quality for the expectations of pediatric patients

The correlation matrix, which is known as the roof of House of Quality (HoQ), was constructed and how engineering characteristics affect each other was determined. The degree of relationship between engineering characteristics was indicated using ' $\bullet$ ' and ' $\circ$ ' symbols, respectively for strong and weak relationships. Cells were left blank when there was no relationship. According to these results, there is a strong relationship between the color of tongue depressors and the usage of non-fearful and non-disquieting materials. Because the use of an 
anxiety-causing material would negatively affect the child's treatment and it would also cause the child to refuse treatment. There is also a strong relationship between the "introduction of treatment equipment" and "psychological preparation programs". For example; if the materials are introduced within the pre-operative psychological preparation programs, the anxiety of the child who undergoes an operation can be reduced. There is a strong relationship between "color of serum hangers" and "usage of non-fearful and non-disquieting materials". While there is a strong relationship between "usage of non-fearful and non-anxiety (non-disquieting) materials" and "usage of nurse and doctor uniforms in various colors and patterns", there is a weak correlation between "providing explanatory information to the child and her/his family". This is because, although explanatory information is given about the place of use and benefit status of medical and technical equipment in treatment to reduce the fear level of children, this explanation may not be effective for every child and family. There is a strong relationship between "usage of nurse and doctor uniforms in various colors and patterns" and "psychological preparation programs". Many children are afraid of the uniforms of doctors and nurses, and this situation causes the child to avoid health personel and treatment. In order to eliminate these negative effects, cartoon characters, geometric figures or colored patterns can be preferred in uniforms. There is a strong relationship between "introduction of the materials used in treatment" and "providing explanatory information to the child and her/his family". There is a strong relationship between "providing explanatory information to the child and her/ his family" and "providing a psychological preparation program". There is a strong relationship between "communicating with other children" and "building play rooms for children". In addition, it was found that there is a strong relationship between "offering psychological preparation programs" and "presenting food specials for children", "giving importance to the visual presentation of meals", "building play rooms", "designing patient rooms", "establishing bookshelves", and "having bed sheets, pillows and rest chair in various colors and patterns".

\section{Conclusion}

This study was carried out in a pediatric hospital with the aim of determining the expectations of pediatric patients from the hospital and to identify the way of meeting their expectations. This hospital is a tertiary healthcare organization in Niğde, a city located in the central Anatolian part of Turkey, and serves under Niğde Ömer Halisdemir University. The expectations of pediatric patients were evaluated in terms of some factors such as service environment, personnel-patient interaction and accommodation services. The sub-criteria of these three factors were also taken into conderation. Accommodation services was found as the most important factor or main criterion, and arrangement of the patient rooms as the most important sub-criterion. All other main and sub criteria were evaluated and prioritized in the study. 
Based on the findings of the study, the following comments and suggestions can be derived: In the current state; the rooms were designed as appropriate for adult patients and not for children. Especially in long-term hospitalizations, children dream of a hospital environment that makes them feel at home. For this reason, a game room can be designed, where children can interact with each other and perform various activities such as playing games, painting, reading books, etc., and child rooms should be redesigned, and thus, become colorful and patterned. Hospitals present standard meals for both adults and children without difference. According to pediatric patients, the meals are not delicious, and they judge the food as unpleasant, unsalted and bad. This situation leads children to refuse meals and negatively affect the treatment process. This can be avoided by serving child-oriented food and putting emphasis on presentation. Another important issue is the design of the materials that are used during the child's treatment process. At this point, it can be considered to avoid materials having fearful and strange designs, and prefer the ones which are colorful, patterned, and interesting. In addition to aforementioned points; information must be given about the treatment process according to the child's age, a healthy communication between health personnel and children must be established, and a home-similar environment must be built from the moment the child takes the first step into the hospital.

The expectations of an adult from healthcare are different from that of children. While adult individuals consider factors such as cleaning, safety, doctor's knowledge, children give more importance to visual elements and personnel behavior. There are many studies in the literature about the expectations of children from pediatric services. However, in these studies, children's expectations from the hospital were measured by asking their parents. Parents may not fully reflect their children's views. One-to-one interviews with children enable them to express their opinions, feelings and expressions more easily. The purpose of this study was to identify expectations from the child's perspective and to find solutions to meet these expectations. This situation revealed the original aspect of the study.

Like other studies, this study had some limitations. Firstly, it was conducted in a single pediatric hospital in a micro level, and secondly, the scope of the sample was restricted to children aged 7 to 12 and excluding emergency patients and the ones who had severe and/ or infectious diseases. Therefore, future research can consider dealing with different and/or multiple hospitals, and expand the scope of the sample used in this study. The findings of this study can be used as a baseline by other researchers, all shareholders of healthcare sector, and management of healthcare organizations and especially other pediatric hospitals. However, it can be easily stated that the decision makers of all pediatric healthcare organizations may utilize the model developed in the present study.

Peer-review: Externally peer-reviewed.

Conflict of Interest: The authors have no conflict of interest to declare.

Grant Support: The authors declared that this study has received no financial support. 


\section{References}

Ahmed, M., Islam, R., \& Al-wahaibi, S. K. (2006). Developing quality healthcare software using quality function deployment: a case study based on Sultan Qaboos University Hospital. International Journal of Business Information Systems, 1(4), 408-425.

Aktepe, A., Ersöz, S., Hayat, Y., Orhan, G., Can, C., \& Çiftçi, S. (2011). Integrated use of servqual analysis and fuzzy analytical hierarchy process (FAHP) in quality function deployment (QFD): an application in a university hospital. XI. Production Research Symposium, 23-24 Haziran 2011. 237-246.

Ardıç, K., Çevik, O., \& Göktaş, Ş. (2008). Quality function deployment: an application at GOP University. Academic Reviews, 3(2), 112-139.

Antmen, ZF., \& Minç, P. (2018). Çocuk yoğun bakım ünitesinde çok kriterli karar verme ile mekanik ventilatör seçimi ve bir uygulama örneği. Çukurova Üniversitesi Mühendislik Mimarlık Fakültesi Dergisi, 33(4), 17-30.

Ariani, N. N., Napiyani, N. M., \& Wijaya, I. P. (2017). Implementatıon of quality function deployment to identify priority needs of customers and health providers of child-friendly community health centre. $P u b$ lic Health and Preventive Medicine Archive, 5(1), 12-17.

Bang W., \& Chang B. Y. (2013). Quality factor analysis of metalworking process with AHP, International Journal of Production Research, 51(19), 5741-5756.

Chan, L. K., \& Wu, M. L. (2002). Quality function deployment: a literature review. European Journal of Operational Research, 143, 463-497.

Chang, H., \& Kim, D. (2010). A quality function deployment framework for the service quality of health information websites. Healthcare Research Information, 16(1), 6-14.

Chang Y., Yang Y., \& Dong S. (2018). Comprehensive sustainability evaluation of high-speed railway (HSR) construction projects based on unascertained measure and analytic hierarchy process. Sustainability, 10(2), 1-19.

Chen C.W., Huang S. H. (2011). Implementing KM programmes using fuzzy QFD, Total Quality Management \& Business Excellence, 2(4), 387-406.

Chiou, C. C., \& Cheng, Y. S. (2008). An integrated method of kano model and qfd for designing impressive qualities of healthcare service. 2008 IEEE International Conference on Industrial Engineering and Engineering Management, 590-594.

Chou, S. (2004). Evaluating the service quality of undergraduate nursing education in taiwan - using quality function deployment. Nurse Education Today, 24(4), 310-318.

Chou, Y. C., Tsai, P. C., Pai, J. Y., Yen, H. Y., \& Lu, C. H. (2014). Application of Kano's two-dimensional quality model and QFD on a gender-friendly environment of hospital. Proceedings of PICMET '14 Conference: Portland International Center for Management of Engineering and Technology; Infrastructure and Service Integration, 3322-3331.

Chung J.S., \& Na G. T. (2018). A study on the feasibility assessment model of urban utility tunnel by analytic hierarchy process. Journal of Korean Tunnelling and Underground Space Association, 20(1), 131-144.

Dehe, B., \& Bamford, D. (2017). Quality function deployment and operational design decisions- a healthcare infrastructure development case study. Production Planning and Control, 28(14), 1177-1192.

Di Mauro, R., Faggiano, F., Andellini, M., Derrico, P., \& Ritrovato, M. (2019). PP179 Health technology assessment of pediatric intensive care ventilators. Cambridge University Press, 35(1), 70-71.

Doğan, Ö., \& Arıcan, R. (2008). Applicatıon of quality function deployment matrix in pharmacology sector. Journal of Business Administration, 9(1), 107-123. 
Einspruch, E. M., Omachonu, V. K., \& Einspruch, N. G. (1996). Quality function deployment (QFD): application to rehabilitation services, International Journal of Health Care Quality Assurance, 9(3), 41-46.

Faggiano, F., Andellini, M., Nocchi, F., Capussoto, C., Sapusco, F., Derrico, P., \& Ritrovato, M. (2017). VP47 Health technology assessment of intensive care ventilators for pediatric patients. Cambridge University Press, 33(1), 168-169.

Falsini D., Fondi F., \& Schiraldi M.M. (2012). A logistics provider evaluation and selection methodology based on AHP, DEA and linear programming integration, International Journal of Production Research, 50(17), 4822-4829.

Ge Z., \& Liu Y. (2019). Analytic hierarchy process based fuzzy decision fusion system for model prioritization and process monitoring application. IEEE Transactions on Industrial Informatics, 15(1), 357-365.

Gonzales, M. E., Quesada, G., Urrutia I., \& Gavidia, J. V. (2006). Conceptual design of an e-health strategy for the spanish health care system. International Journal of Health Care Quality Assurance, 19(2), 146-157.

Gündoğdu, S., \& Görener, A. (2017). Process improvement using quality function deployment in the healthcare sector. Alphanumeric Journal, 5(1), 128-146.

Hancerliogullari, G., Hancerliogullari, KO., \& Koksalmis, E. (2017). The use of multi-criteria decision making models in evaluating anesthesia method options in circumcision surgery. BMC Medical Informatics and Decision Making, 17(14), 1-13.

Hashemi, N., Marzban, M., \& Delavari, S. (2015). Quality function deployment: application to chemotherapy unit services. Middle East Journal of Cancer, 6(4), 219-228.

Hu, C. M., \& Yeh, C. H. (2011). The synergy of QFD and TRIZ design practice- a case study for medical care bed. Proceedings of 2011 International Conference on Modelling, Identification and Control, Shanghai, China, June 26-29. DOI: 10.1109/ICMIC.2011.5973760

Javid R. J., Nejat, A., \& Hayhoe, K. (2014). Selection of CO2 mitigation strategies for road transportation in the united states using a multi-criteria approach. Renewable and Sustainable Energy Review, 38, 960-972.

K1dak, L., Arslan, E., \& Burmaoğlu, S. (2016). Is voice of patient heared? An application of fuzzy-ahpweighted quality function deployment in public hospital. International Journal of Alanya Faculty of Business, 8(2), 93-107.

Khare, S., \& Sharma, J. (2013). From conception to creation quality function deployment in health sector. Mathematics and Computers in Contemporary Science, 84-89.

Kuo, R. J., Wu, Y. H., Hsu, T. S., \& Chen, L. K. (2010). Improving outpatient services for elderly patients in taiwan: A qualitative study. Archives of Gerontology and Geriatrics, 53(2011), 209-217.

Lin, M., Zeng L., Huang, L., Tao Y., \& Zhang L. (2020). Application of Delphi method and analytic hierarchy process to establish indicator system for evaluation of rational drug use in children with primary nephrotic syndrome. Medicine, 99(19): p e19949. doi: 10.1097/MD.0000000000019949.

Matzler, K., \& Hinterhuber, H. H. (1998). How to make product development projects more successful by integrating KANO's model of customer satisfaction into quality function deployment. Technovation, 18(1), 25-38.

Morris L. J., \& Morris J. S. (1999). Introducing quality function deployment in the marketing classroom. Journal of Marketing Education, 21(2), 131-137.

Oktafianto, M., Akbar, Y., Rizgi, A. Fitrian, A., \& Maseleno, A. (2018). Dismissal working relationship using analytic hierarchy process method. International Journal of Pure and Applied Mathematics, 118(7), 177-184.

Özgener, Ş. (2003). Quality function deployment: a teamwork approach. Total Quality Management \& Business Excellence, 14(9), 969-979. 
Park, S. H., Ham, S., Lee, M. A. (2012). How to improve the promotion of Korean beef barbecue, bulgogi for international customers. An application of quality function deployment. Appetite, 59(2), 324-332.

Radharamanan, R., \& Godoy, L. (1996). Quality function deployment as applied to a health care system. International Conference on Computers and Industrial Engineering, 31(1/2), 443-446.

Radivojeviç, G., \& Gajoviç, V. (2014). Supply chain risk modeling by AHP and fuzzy AHP methods, Journal of Risk Research, 17(3), 337-352.

Saaty, T. L. (2008). The analytic hierarchy and analytic network measurement processes: applications to decisions under risk. European Journal of Pure and Applied Mathematics, 1(1), 122-196.

Shih, H. S., \& Chen, S. H. (2016). A conceptual design of a mobile healthcare device-an application of threestage QFD with ANP and TRIZ. International Journal of Operations Research, 10(2), 80-91.

Shuo- Fang, L., Lee, Y. \& Huang, Y. (2009). A brief fatique inventory of shoulder health developed by quality function deployment technique. Journal of Shoulder and Elbow Surgery Board of Trustees, 18, 418-423.

Türkiye İstatistik Kurumu (TÜIK) [Turkish Statistical Institute] (2018). Child with Statistics. (01/09/2019).

United Nations (UN) (2017). World Population Prospects. (03/09/2019) https://population.un.org/wpp/Publications/Files/WPP2017_DataBooklet.pdf.

Varajao, J., \& Cruz-Cunha, M. M. (2013). Using AHP and the IPMA competence baseline in the project managers selection process, International Journal of Production Research, 51(11): 3342-3354.

Yang, Y., \& Kim, M. (2013). Analysis of user requirement on u-healthcare system. International Journal of Business Tourism and Applied Sciences, 1(2), 1-10.

Yaprakl1, T. Ş., \& Güzel, D. (2010). Quality function deployment in healthcare sector. Selçuk University Journal of Social Economic Research, 13(19), 458-476.

Yu, Y., Jia, L., Meng, Y., Hu, L., Liu, Y., Nie, X., Zhang, M., Zhang, X., Han, S., Peng, X., \& Wang X. (2018). Method development for clinical comprehensive evaluation of pediatric drugs based on multi-criteria decision analysis: application to inhaled corticosteroids for children with asthma. Pediatr Drugs, 20, 195-204.

Zhang, L., Lavagnolo, M.C., Bai H., Pivato, A., Raga, R., \& Yue, D. (2019). Environmental and economic assessment of leachate concentrate treatment technologies using analytic hierarchy process. Resources, Conservation \& Recycling, 141, 474-480.

World Health Organization (WHO) (2019). Recognizing adolescence (02/10/2019). http://apps.who.int/adolescent/second-decade/section2/page1/recognizing-adolescence.html 


\section{APPENDIX}

Appendix 1

Patient expectations measurement criteria interview questions

\begin{tabular}{|c|c|c|}
\hline & Expectations of Patients & Questions About Criteria \\
\hline \multirow[t]{4}{*}{ Service Environment } & $\begin{array}{l}\text { Appearance of Treatment } \\
\text { Equipment }\end{array}$ & $\begin{array}{l}\text {-Do you think the materials used in the treatment are fear- } \\
\text { ful and worrying? } \\
\text {-Would you like the materials used in the treatment to be } \\
\text { colored and patterned? } \\
\text {-Do the materials used in treatment affect your happiness in } \\
\text { the hospital? }\end{array}$ \\
\hline & Clothes of Hospital Personnel & $\begin{array}{l}\text {-Do the clothes by doctors and nurses create fear and anxi- } \\
\text { ety? } \\
\text {-Do the clothes that doctors and nurses wear affect your } \\
\text { happiness in the hospital? } \\
\text {-What kind of clothes would you like doctors and nurses } \\
\text { to wear? }\end{array}$ \\
\hline & Care Information for Disease & $\begin{array}{l}\text {-Do you want to be informed by the doctors and nurses } \\
\text { about the equipment used in the treatment? } \\
\text {-Would you like a photo to be displayed about your illness? } \\
\text {-Would you want stories to be told about your illness? } \\
\text {-Would you want to see a movie to about your illness? }\end{array}$ \\
\hline & Treatment Services & $\begin{array}{l}\text { - Do you want to be informed by doctors and nurses about } \\
\text { what kind of treatment you have been given? } \\
\text {-Do you understand what the doctors and nurses say about } \\
\text { your treatment? } \\
\text {-Do you want to play therapeutic games (blowing bubbles, } \\
\text { blowing bubbles for improving lung function)? }\end{array}$ \\
\hline \multirow[t]{3}{*}{$\begin{array}{l}\text { Personnel-Patient } \\
\text { Interaction }\end{array}$} & Behaviors of Doctors & $\begin{array}{l}\text { - How do you want doctors to communicate with you? } \\
\text { - Do you think doctors approach you with love and affec- } \\
\text { tion? }\end{array}$ \\
\hline & Behaviors of Nurses & $\begin{array}{l}\text { - How do you want the nurses to contact you? } \\
\text { - Do you think the nurses approach you with love and } \\
\text { affection? }\end{array}$ \\
\hline & $\begin{array}{l}\text { Behaviors of Other Health } \\
\text { Personnel }\end{array}$ & $\begin{array}{l}\text { - How do you want other medical personnel to contact you? } \\
\text { - Do you think other medical staff approach you with care } \\
\text { and love? }\end{array}$ \\
\hline \multirow[t]{4}{*}{ Accomodation Services } & Nutrition Services & $\begin{array}{l}\text {-Are you happy with the food you ate in the hospital? } \\
\text {-What food do you want to eat at the hospital? }\end{array}$ \\
\hline & Arrangement of Patient Rooms & $\begin{array}{l}\text { - How can you arrange the room in the hospital? } \\
\text { - You want to feel at home in the hospital? } \\
\text { - Do you want to be with your friends in the hospital room? }\end{array}$ \\
\hline & Appearance of Rest Chairs & $\begin{array}{l}\text {-You want the rest chairs to be colored and patterned? } \\
\text {-Do the color and pattern of the rest chairs affect your treat- } \\
\text { ment positively? }\end{array}$ \\
\hline & Appearance of Patient Beds & $\begin{array}{l}\text {-You want the beds to be colorful and patterned? } \\
\text {-Will the comfort of the beds affect your treatment posi- } \\
\text { tively? }\end{array}$ \\
\hline
\end{tabular}




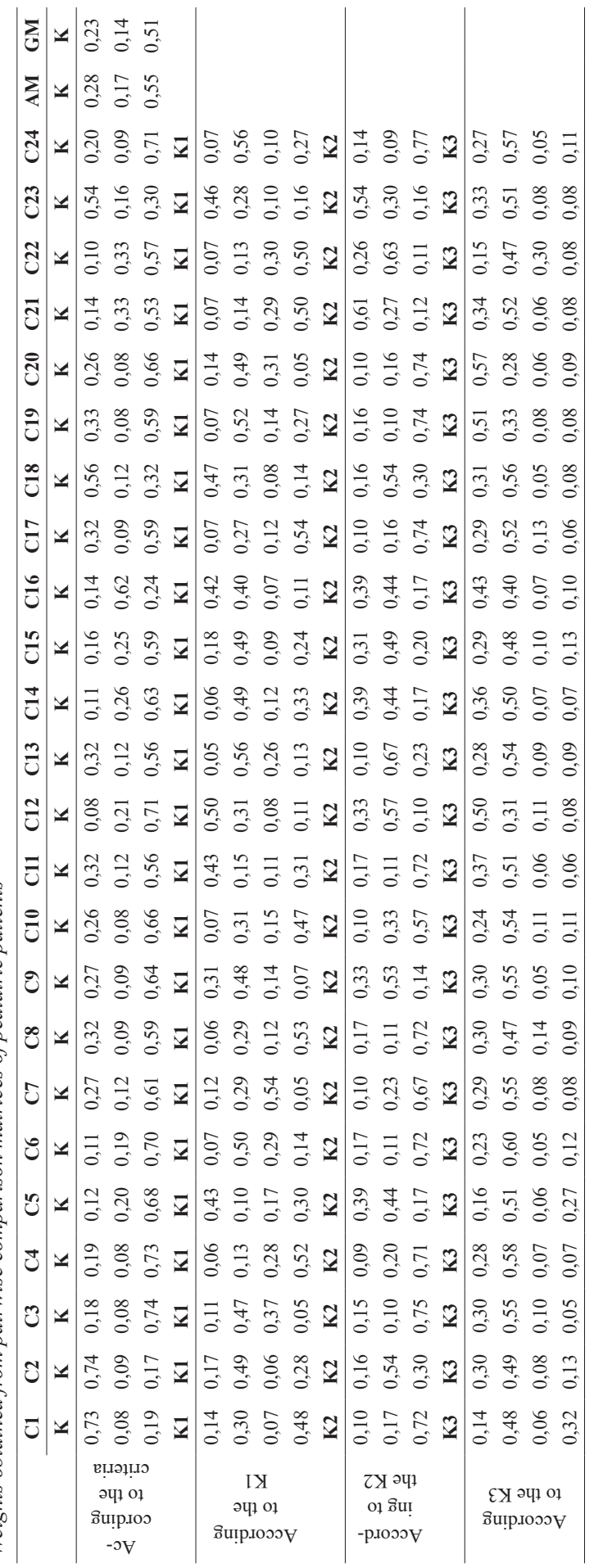




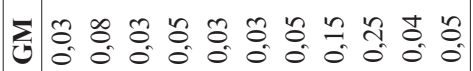

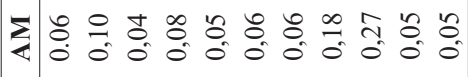

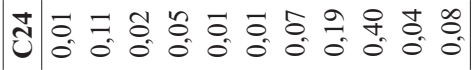

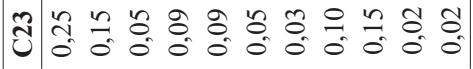

สี

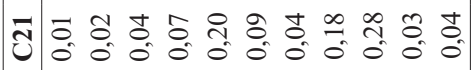

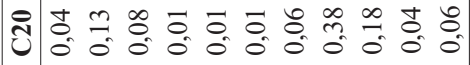

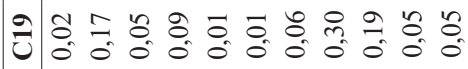

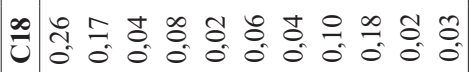

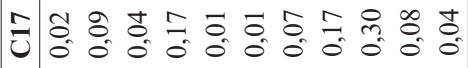

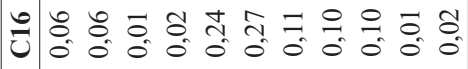

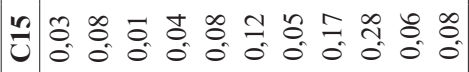

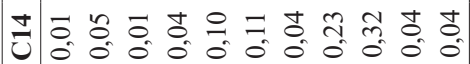

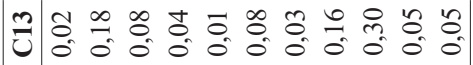

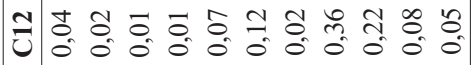

๘

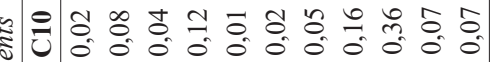

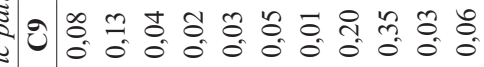

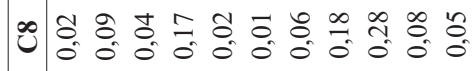

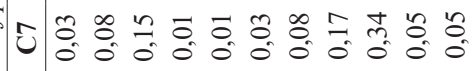

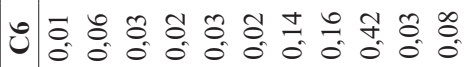

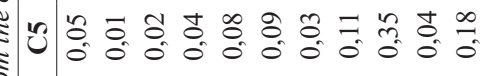

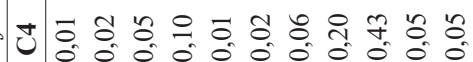

잉

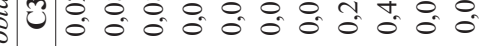

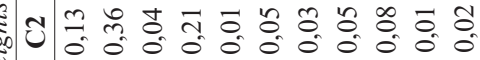

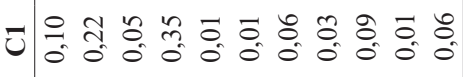

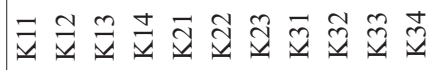

